\title{
'Up close and personal' - How does local democracy help the poor access the state? Stories of accountability and clientelism in Johannesburg
}

\begin{abstract}
Claire Bénit-Gbaffou ${ }^{1}$
Abstract

The paper revisits participation and decentralization in relation to local clientelism, arguing that they share the personalization of links between residents and the State and the local possibility to adapt state policies. The line between decentralization-participation on the one hand, and clientelism on the other, is therefore easily blurred. The paper thus argues that clientelism is not per se anti-democratic, some forms allow for local and immediate accountability of politicians. However, in most cases, it contributes to fragment or sedate local organizations or social movements and it prevents contestation of existing policies and dominant power structures. The paper thus challenges the idea that the promotion of decentralization and participatory institutions intrinsically leads to more democratic forms of government.
\end{abstract}

\section{Key words:}

clientelism, decentralization, participation, accountability, Johannesburg, South Africa.

\section{Two stories on clientelism and accountability}

The two stories that follow take place in a low-income inner city neighbourhood of Johannesburg divided into two electoral wards, both marked by significant electoral competition, an exceptional occurrence in Johannesburg prior to the 2008 elections, where the African National Congress (ANC) had a strong majority in most wards. This competition had led, in both wards, to the victory of opposition parties in the 2006 municipal elections: one led by the Inkatha Freedom Party (IFP) and the other by the Democratic Alliance (DA). While this makes the stories specific, perhaps rendering more visible issues of accountability and clientelism, they are far from exceptional in low-income areas of post-apartheid Johannesburg. Here, we use these stories as emblematic of local political dynamics, ${ }^{2}$ as a means to query assumptions made about the relationship between practices of local democracy and clientelism.

\section{Story One}

In this low-income inner-city neighbourhood, the municipal administration wanted to distribute food parcels to the poor - only a limited number were to benefit as resources were scarce. In the name of 'proximity' to the ground and a better knowledge of needy households (of which there were many in the area), the City asked SANCO (South African National Civic Organisation, a major residents' organization in the $\operatorname{area}^{3}$ ) to choose the beneficiaries and organise their distribution.

It seems that SANCO distributed the parcels to its own members, no less needy than non-members: in a context where poverty is rife and public goods scarce, what legitimate criteria can distinguish those in need, especially for such insignificant public goods? ${ }^{4}$ However small these advantages are, they play an important role in residents' everyday hopes, expectations, and tactics. These types of advantages can explain the civic's sustained popularity in the neighbourhood, in spite of many rumours about some level of dishonest practices. One of these, reported by several residents and local leaders, mentions in particular the collection of fees from members in exchange for a promise of access to public housing. ${ }^{5}$ 
Another, more ambiguous in its effect, reports that SANCO, generally known for defending tenants on the verge of being evicted by their landlords, is sometimes one of the evictors, and uses the houses it has taken over, or 'hijacked', to accommodate its own members.

\section{Story Two}

In the same neighbourhood, another group of residents (about a hundred people living in a quite distinct cluster of council houses next to a stadium, and calling themselves 'the seventeen houses'), managed to negotiate with 'the State' to avoid eviction in the context of the 2010 World Cup. These residents had important political resources, as many were longstanding ANC anti-apartheid activists, and therefore maintained dense political networks within both the party and the state. Already, in 1995 in preparation for the Rugby World Cup, the City tried to demolish the seventeen houses, which were in fact an 'oddity' in a precinct devoted to international sporting facilities. Residents had retorted, successfully, 'How can you betray us, just after we've put you in power?' However, in the preparation for the 2010 Soccer World Cup, once again, the municipality intended to remove this cluster of houses in order to build a shopping mall to encourage international visitors to spend money during the one-month mega-event. In 2009, the residents' committee contacted a non-government organization (NGO), the Center for Applied Legal Studies (CALS), well-known for its successful lawsuits against the City of Johannesburg. After a few months of joint action during which CALS had sent letters to the City requesting information regarding the fate of its 'clients' and threatening to sue in case of non-response, the residents' committee suddenly changed tactics and attacked CALS, accusing the NGO of being 'racist', 'anti-ANC', betraying the nation as 'trying to undermine the foundation' of the post-apartheid democratic state, 'promoting a culture of non payment' and orderlessness. It seems likely that the residents' committee negotiated with the City of Johannesburg, through their linkages to high ranking ANC party or City officials, with the trade-off: the City would abandon the eviction ${ }^{6}$ and residents would drop the lawsuit and terminate their relationship with CALS.

What do these two stories tell us about a poor neighbourhood's access to the state in postapartheid Johannesburg? They certainly point to the messy character of local democracy, and the often odd ways in which participation, decentralization, and clientelism interact. Participation is understood here as the modalities and extent to which residents have a say (through 'invited' or 'invented' spaces of participation (Miraftab 2004); through elected but also non-elected local representatives (such as the residents' committee, civic association, or NGOs), in their direct environment or in the local allocation of public resources. Decentralization is meant here as the transfer of power and responsibilities at a local level, based on the belief that knowledge is embedded 'on the ground' and that the local scale is more responsive to specific needs. ${ }^{7}$ And clientelism can be provisionally defined as the granting (by politicians to voters) of public goods based on personal networks and influences rather than on a well-established and clear set of principles and rights. The objective of this paper is to unravel this messiness, and confront and compare the theoretical tenets of each of these blurred concepts (participation, decentralization, clientelism) that are mostly addressed in distinct and separate literature and disciplines. I will start with a reflection on the theoretical disjuncture that operates in most literature between local democracy on the one hand, and clientelism on the other. A second part of the paper will explore the theoretical and practical similarities between the two notions; finally I will consider the consequences of this similarity for local democratic accountability for low-income residents in Johannesburg. 


\section{Local democracy and clientelism: a theoretical or disciplinary disjuncture?}

The local level is often perceived as more democratic than other scales of government, as it offers citizens the possibility of directly liaising with elected representatives, and therefore holding them to account, especially on local issues that affect their daily lives. Purcell (2006) has warned about the danger of worshipping the local scale, arguing it holds nothing inherently more democratic than others. However the local scale is certainly specific in the potential it offers for interpersonal contacts between residents and their representatives, for a more 'humane', flexible and locally-grounded State. In addition the local scale offers the potential for policy makers to grapple with the challenges of implementing their policies, and also with the effects of these policies on their direct constituencies (John 2009). This potential for greater State accountability has been one of the key driving forces for decentralization as well as local participation in recent decades, all around the world; the other driving force being, especially in African societies, the globally-driven, neoliberal attempt to weaken or side-line the central State considered corrupt and inefficient. In African cities, this plea for both a greater decentralization and an enhanced participation of civil society in urban governance has been reinforced by the understanding that central states do not control many of the urban dynamics currently shaping African cities (Swilling, 1997). Local democracy therefore is seen as the way to build democracy and achieve efficient urban governance.

Often the local scale is assumed to be more democratic due to an increased level of accountability of office bearers thanks to personal, direct and ordinary contacts with the voters. One cannot but be struck by the possible clientelist nature of such links, however, which precisely rely on personal, binding relationships between elected representatives and their voters. Whereas many South American scholars have argued that the development of local democracy (understood here in its two dimensions of decentralization and participation) is a way out of what they conceive as 'traditional clientelism', or patronage (Abers 1998; Gay 1998), this paper argues the contrary: local democracy might well be conducive to clientelism as it rests on similar principles (personalisation of relationships between citizens and the State; flexibility and adaptability of policies to local contexts).

Political clientelism has been defined in many ways (Médard 1973; Briquet and Sawicki 1998; Kitschelt and Wilkinson 2007) and has taken many forms depending on context, scale and focus, for instance patronage, prebendalism, patrimonialism, or neo-patrimonialism. Here we follow Kitschelt and Wilkinson (2007), who define it as a direct exchange between a politician and a voter, of public goods (given as 'favours') for political support (vote and other). This definition is specific in a number of respects. First, it is not necessarily an individual relationship between two agents, even though it is a 'direct' relationship relying on personalized linkages. It can develop between a politician and a group in which case we speak of collective clientelism. Second, political clientelism is about the distribution of public goods such as public housing, employment contracts, and access to social services, for instance. Third, political clientelism is not merely about the vote, political support takes many forms (as outlined by Auyero 1999); participating in party rallies, being the party watchdog in public or local meetings, for instance. Finally, it is a non-normative definition that excludes moral judgement but attempts to analyse existing dynamics and mechanisms linking voters and political representatives.

Clientelism is almost universally described as an evil, largely responsible for the failure of democracy in Africa: precisely what global institution-driven principles of 'good governance' fight against (World Bank 2000; Keefer 2002; Keefer 2005), in particular (and 
paradoxically) through decentralization and residents' participation in urban governance (World Bank 1996; Brinkhoff and Goldsmith 2002). Many World Bank reports interestingly highlight that decentralization and governance reform might provide space for clientelism (Keefer 2002; Keefer 2005); but they understand clientelism as radically opposed to democracy. What we wish to argue here is that clientelism and local democracy are intertwined, in practice and, possibly more importantly, in their principles. We argue, therefore, that to draw normative lines between supposedly 'good' (democratic), and 'bad' (clientelistic) relationships between a citizen and her elected representative might be counterproductive task.

Instead, this paper considers whether there are analytical tools to understand in what circumstances local democracy leads to clientelism, and in which cases it does not. Or, as argued by a number of Latin American scholars (Gay 1999; Auyero 1996; Auyero 1999) and also theorists from the North (Kitschelt and Wilkinson 2007), whether there is essentially a continuity between local democracy and clientelism, which relies on forms of exchange of votes for public deliverables, and which at times provides for accountability. The objective here is not only to provide a more subtle understanding of clientelism, as a de facto form of accountability in certain conditions ${ }^{8}$ - but also to highlight how, similarly to clientilism, decentralization and local participation can lead, if uncritically praised, to undemocratic practices and ultimately to the disempowerment of the poor.

While several studies assess the impact of decentralization on corruption, poverty alleviation or development (see e.g. Bhardan and Mookherjee 2006), few reflect on the theoretical and practical proximity of these three notions, and unravel at the local level the complex mechanisms of party politics in the daily practice of urban governance (Williams 2004). Why is that so? Following Low (2007), local party political dynamics and their influence in urban governance and local democracy are seldom studied on their own (see Benit-Gbaffou, forthcoming). On the one hand, scholars in political studies consider party politics (which lie at the core of clientelism) as of little importance at local level, compared to national or regional level politics. On the other hand, they are often seen by other social scientists as too dirty and messy, driven by power-hungry individuals, perhaps appearing 'inauthentic' (whatever that may mean) compared to residents' social movements (McAdam et al 1996; Ballard et al 2006), the politics of everyday resistance (Scott 1998; Bayat 1997), or participation (Cornwall 2008). Occasionally, the importance of party politics in low-income residents' everyday lives is stressed (Simone 2004; Tostensen et al 2001), but it is seldom analysed and only mentioned as a possible impediment to civil society's supposedly meaningful, progressive, and autonomous democratic participation. We see thus a general reluctance to open the 'black box' of petty politics that characterize residents' (supposedly) progressive movements, or a lack of interest in the dynamics of the micro-local scale of urban governance. This gap has been produced in the disciplinary silos that seal our debates. Here, we attempt to bring these threads together to explain political and social dynamics observed on the ground to make two related points: first, that there is a practical, but also theoretical proximity between decentralization-participation and local clientelism; second, that the notion of accountability links in complex and unexpected ways to local democracy on the one hand, and clientelism on the other.

\section{The practical and theoretical proximity of decentralization-participation-clientelism}

A highly positive connotation is usually associated with the notions of decentralization and participation and the inter-relationship between them in direct contrast and opposition to the 
generally negative understanding of clientelism. Both decentralization and participation have attracted massive intellectual and political support, both from progressive academics and activists, and from neo-liberal global institutions (World Bank 1996; World Bank 2000). ${ }^{9}$

Critical approaches to decentralization and participation have remained limited. As far as internal contradictions of participation are concerned, they have focused mainly on the (necessarily) limited representativity of participatory democracy as opposed to representative democracy (Abers 1998). Others have denounced the capture of local democracy by local elites (or at least 'the empowered'), new or old (Bardhan and Mookerjhee 2004; Veron et al. 2006), at the expense of more marginal groups who remain voiceless in decentralized structures and participatory platforms (Cooke and Kothari 2001; Harriss 2002). Some have also argued that the restriction of public debate around local and immediate issues has proved an efficient way of depoliticising democratic debates, sedating social movements and avoiding more radical questioning of existing power structures and forces acting at broader levels (Cooke and Kothari, 2001; Mohan and Stokke 2000). Much less literature focuses, however, on the nature of local participation and decentralization in relationship to democracy, and its potential to give rise to un-democratic processes (Staniland 2008; Veron et al 2006). This oversight reflects an entrenched notion that 'communities' (especially lowincome ones) cannot be wrong or exclusionary, and thus participation is rarely understood or theorized as 'conservative'. By stressing the proximity of participation and decentralization to clientelism, we allow for a deeper analysis of the relationship between participationdecentralization and democracy, and for the introduction of party politics to the understanding of urban governance (Cornwall and Coelho 2007; Williams 2004).

Kitschelt and Wilkinson's recent work on clientelism (2007) is useful in this regard, as they convincingly argue that, in the analysis of the relationship between politicians and voters (in particular in its dimension of accountability), there is a difference in gradient, rather than in nature, between what they call 'programmatic policies' and 'clientelist policies'. They define 'programmatic policies' as policies benefiting a certain social group, in principle, a posteriori, and therefore indirectly, abstractly; for example, a political programme lifting taxes on business will largely benefit the economic elite, a programme promoting universal medical aid will primarily benefit the poorest. 'Clientelist policies' also benefit certain social groups, but in a more direct way, through less abstract and more personal engagement between the politicians and the beneficiaries or voters and possibly a priori; for example if a politician provides electricity to a neighbourhood, she will expect the neighbourhood to organise voting support for her. Between what are considered two poles of a continuum there are a variety of policies that define a narrower group of beneficiaries in a relationship that is intermediate: not entirely abstract and indirect, not entirely personalized and direct. What is interesting in Kitschelt and Wilkinson's model is the continuum they stress between programmatic and clientelist policies, on the basis that they both rely on a relationship between politicians and voters based on an 'exchange of votes for benefits', those benefits defined more as abstract 'rights' in the first case, more as personal or localized 'favours' in the second; given on the basis of an abstract and legally defined rule in the first case, on the basis of a direct, locally defined arrangement in the second.

This continuum is even more evident in African countries, where the scarcity of public resources, aggravated in the context of structural adjustment programmes, often leads governments to pragmatically transform a programmatic policy (for instance, employment of local residents in local development projects) into a clientelist policy (Khan 2005). This is clearly illustrated in Story One above. What might be considered a fair criterion and selection 
process for beneficiaries of food parcels, when only a limited number of parcels are available; the good is perishable and limited; the potential number of beneficiaries (if selected by their need or income level) is incommensurate? Rather than an impossible administrative criterion that would prove impractical or an open political process that would risk triggering opposition and revolt, a discreet, opaque distribution of resources through existing locally based networks (here SANCO and the ANC) is certainly easier from a management perspective. At the same time, although non-members or opposition-aligned political party groups can challenge such decisions, it is also an informal rule that is understood and de facto accepted by most local residents.

Moreover, decentralization and participation share with clientelist logics two main features. First, they entail an increased personalisation of the relationship between the State and its citizens - far from a Weberian ideal - and in particular between local representatives and their voters. Elected local representatives are supposed to be 'closer' to their constituency as constituencies are narrower and more 'local'. This is so not only during election times, but also between election times as an effect of participation - with elected representatives supposedly 'accessible' to solve everyday problems and concerns of their voters, on a flexible and ad hoc basis. Second, participation and decentralization on the one hand, clientelism on the other, also imply a form of local negotiability and adaptability of public policies. In this they follow the principles of 'good governance' largely adopted by important cities around the world, which broadly state that policies should be the result of negotiation between different levels of government (decentralization, where the local level is supposedly the better informed about local needs and contexts) and between the State and 'local' civil society (participation - in a broad understanding of local civil society including for instance local business groups or business groups with a stake in an area). This spatial (but also temporal) flexibility, according to local contexts and circumstances, departs from a universal, abstract, city, region or nation-wide set of laws and rules, opening the way for local arrangements, or 'negotiated local compromises'. ${ }^{10}$

Personalisation of relationships between politicians and voters on the one hand, flexibility of the law or policy to be adapted and negotiated at the local level on the other, are at the core of clientelist practices. Possibly they both foster a form of greater accountability (in the sense of responsiveness), and a form of opacity of public policies and choices that would tend to lower accountability (in the sense of transparency and questionability). Following this perspective, returning to Story One, one could argue that tasking a civic organisation (SANCO) with the selection of beneficiaries for state-provided food parcels is following some of the principles of decentralization, i.e. finding a way to gather information that is the most locally accurate in order to be able to better focus public policies and distribute scarce public resources to the most needy. It could argued that it follows principles of participation, with the civic organization having a say and a control over resource allocation. Some would argue clientelism is a mere perversion of this practice, even perhaps a double perversion, combining a lack of representativity of the civic (not encompassing all needy residents) with the probable dishonesty of its leadership. They would argue that this approach might have worked if the civic organization had been a 'good one', disentangled from any partisan affiliation and immune to any monetary temptation, a naïve interpretation. The devolution of powers of allocation of public resources to an agent that is not democratically accountable is in itself conducive to undemocratic practices, ${ }^{11}$ whatever the local legitimacy of this agent. Personalisation and opacity of the access to public goods are the rule, and do by definition create space for possible abuse. 


\section{Ambiguities of decentralization-participation-clientelism}

The impact of decentralized and participatory governance modes on democratic accountability is far from obvious, although both claim to enhance accountability and local democracy by rendering local representatives and the state more accessible and more responsive to local needs. The theoretical and practical fine line between those two notions and that of clientelism highlights their 'dark side', stressing the potential opacity and arbitrariness of public policies that tend to weaken State accountability to citizens. It also underlines the possible bright side of clientelism, which is conducive to forms of accountability, despite its real democratic shortcomings.

Here, the distinction between individual and collective clientelism (as expressed for instance in Gay 1999) is crucial. Story One illustrates a case of individual clientelism, with the distribution by SANCO of food parcels to selected individuals, loyal members of the organization, as both a reward for their membership and support, and as a consolidation of such support. But it is also a case of collective clientelism, between the (ANC-led) local municipality and the (ANC-aligned) residents' association, SANCO: the alliance is consolidated and confirmed by the attribution of a collective good to an organization in exchange for it building collective support for the ANC. Using SANCO to distribute food parcels allows the municipality to highlight ANC-led delivery, rather than delegate this task to the DA councillor, more broadly reflecting a high-level party-political competition.

Story Two is purely a case of collective clientelism, where individuals join their voices within a group to fight a public policy, and later to support the party that has granted them a favour after concluding a local bargain. Here, it is the possibility for the group to remain in the area and to avoid having their houses demolished that is at stake, even if the goods distributed are individual dwellings. The point here is that collective clientelism provides for a form of public accountability: the State and the party are finally obliged to take into consideration local residents' claims, rather than simply ignore them. For Gay (1998), collective clientelism is the dominant form of state accountability to the poor, as he argues that the rhetoric of rights seldom reaches them due to the scarcity of public resources and inefficiencies of the State, in the context of Brazilian cities. Clientelism therefore becomes a singular (albeit restricted) means through which the voices of the poor are heard and translated into some form of benefit and access to public goods, collective clientelism leading to the public delivery of collective or at least public goods (such as the electrification of an area or tarring of roads).

This reflection on clientelism also shows how other forms of accountability are undermined by personalized and flexible public practices of allocation of public goods to local beneficiaries; and, in the same ways, how decentralization and participation also can lead to diminished accountability. This argument resonates with well-developed arguments of the 'local trap' (Purcell 2006), of 'the dangers of localism' (Mohan and Stokke 2000), and Cooke and Kothari's (2001) point that the confinement of debates on local and immediate issues legitimizes the broader status quo, since some issues cannot be challenged at the that scale. A focus on clientilism further develops these arguments, taking into account the micro-politics at work in clientelist (but also in decentralized and participatory) practices, which tend to focus on the everyday workings of the state (Fuller and Bénéi 2001; Corbridge et al 2005).

Returning to Story Two, there are several sides to be exposed. It can be seen as a victory for residents of the seventeen houses - they obtained what they wanted through a negotiated process with the City, thanks to the threat of legal action gained through CALS' intervention. 
Local residents were able to mobilize for their best immediate advantage with the political resources they had (through linkages to the NGO as well as to the ANC), alternatively using threat, conflict, cooperation and compromise. The result is a success, both practical (no eviction) and political (links with the ANC have been maintained and possibly reinforced), even though the links with CALS have been sacrificed. It can be seen as a successful form of participation. However, this success can also be seen as a setback for the broader local community affected by urban renewal and eviction threats, and for CALS, which hoped to see and support the emergence of a broader residents' movement fighting evictions in the whole area. CALS' dismissal by residents, who are quite powerful local leaders, does not make future action easy for the legal NGO, at least not at a collective or public scale. The City, on the other hand, has managed to limit the political impact of this victory, in a context where more evictions are taking place, publicly and privately led, in a slow but steady move towards urban regeneration, at the expense of often less organised and less politicallyresourced groups of residents. Their final acceptance of residents' claims to stay in their area has not been the result of a public debate and the affirmation of a right of residents to have a say on their neighbourhood; rather, it has been negotiated behind closed doors as a favour, due to exceptional circumstances and for the benefit of a specific set of former political activists. In other words, collective clientelism in the language of favour and political loyalty has destroyed the possibility of social movement mobilization in the language of rights and legal confrontation with the state.

More generally, local negotiations and immediate advantages, be they collective ones (like in Story Two) or, more frequently, individual ones (as in Story One), lead to the fragmentation of more radical contestations and the sedation of more critical social movements. Whilst we agree with some authors (Auyero et al 2009) that clientelism and collective mobilization are not always contradictory and often rely on the same social and political networks, and that patrons sometimes have an interest in triggering collective movements of contention in a dominant party system such as South Africa's, most clientelistic networks seem to work towards maintaining the status quo (at least when it comes to challenging government and its policies) and the muting of more radical contentious movements.

How can we understand the paradox that decentralization, participation and clientelism simultaneously seem to increase and decrease state accountability to urban citizens? Story One shows a pragmatic way of distributing scarce minor public goods to local residents, through a (clientelistic, decentralized, participatory) discrete and more or less locally accepted way. It provided access to public goods to some low-income residents; but did not allow for claims to be built publicly or collectively about the nature, quantity and distribution modalities of the public goods granted. Story Two led to a victory for low-income residents who, initially confronted with an impossible threat, managed to resist a powerful World-Cup led drive for urban regeneration, thanks to personal political and social networks of local leaders. The State granted the request, but it also undermined the possibility for broader policy change.

Certainly at a theoretical level, one needs to unpack in this paradox the notion of accountability, often taken for granted and under-theorized. Schedler (1999) distinguishes between two dimensions of accountability: 'answerability' of the power-holders (to provide information and to provide justification for their action) and their sanctionability (risk of being removed from office if they fail to deliver or to answer). Both are central to the debate on decentralization and participation, supposedly promoting a better responsiveness to citizens' needs; and, both are, more broadly, relevant to the debate on substantive democracy 
(Harriss et al 2004). An alternative and operational definition of accountability at the local state level could differentiate between two dimensions: the first measuring the State's reactivity and responsiveness to specific contexts; and the second concerned about transparency and the possibility for citizens to question local policies and practices. This would explain why decentralization, participation and actually, clientelism, can be simultaneously said to enhance one dimension of accountability, responsiveness or reactivity, at least for those residents who are politically resourced and connected; and to undermine another, transparency or questionability. Although the dichotomy is quite simplistic, the first dimension puts a stress on governance efficiency; the second is more of a democratic and political concern.

\section{Conclusion: Debates on African cities' governance}

Existing literature on local democracy in African cities stresses four key characteristics that mark urban governance: first, the importance of personal networks as major means of survival for the poor (Swilling 1997; Tostensen et al 2001; Simone 2004); second, the multiplicity of levels of leaderships and group affiliations, of varying nature and with different, often competing, types of legitimacies (from traditional chiefs to local party representative, for instance) (Rakodi 2002; Simone 2004; Akinyele 2006); third, the fluidity and ephemeral character of urban governance and power patterns (Simone 2004; Lindell 2008) that render northern concepts such as 'urban regimes' or 'growth coalitions' unsuitable to describe much more flexible African urban realities; and fourth, the lack of independence of civil society organizations towards political parties and their embeddedness in clientelistic relationships with the State at all levels, said to compromise their ability to challenge the State and work towards the consolidation of democracy or the empowerment of the poor (Tostensen et al 2001; Rakodi 2002; Watson 2002). It is useful to bring these quite specific characteristics of African urban governance into conversation with our reflection on decentralization, participation and clientelism.

Decentralization adds another layer of political legitimacy and of leadership - that of the local councillor - to those already existing; participation provides another arena for interaction, negotiation and access to urban goods - in particular around urban projects, more or less empowering and more or less influenced by international institutions' demands. This reinforces the first two characteristics of urban governance in African cities outlined above: decentralization and participation do empower local residents by broadening the limited range of existing opportunities to voice their needs and access public goods - not necessarily on a radically different model from previous opportunities and channels (as these political opportunities still rely on direct and personalized linkages between client and patron), but at least offering an additional option.

However, as illustrated in this paper ${ }^{12}$, decentralization and participation can also easily increase the fragmentation of broader social movements as well as promote the sedation of more radical claims for political or structural changes of resource allocation, particularly as their independence from party politics is further compromised. These dynamics affirm the social and economic status quo, where the weaker (in terms of economic as well as political resources) are further marginalized and the politically networked manage to maintain their own position and possibly rise on the political or economic ladder, without challenging the existing power structure. In this sense, our paper contradicts the third characteristic outlined above. The idea of fluidity and instability of power patterns in African urban governance is problematic in that it discards the notion of reproduction of unequal power structures, and 
denies the possibility of the overall stability of political leaders or patrons. They may remain in power even when their power platform, legitimation discourse and types of alliances change according to political and economic opportunity - giving an impression of fluidity, while in real terms nothing changes.

Third, decentralization and participation dynamics are likely to reinforce the importance of the role of political parties in civil society. Indeed, they aim at least rhetorically to strengthen the power of civil society organizations in urban governance, which therefore become more important a stake for political parties' competition at the local level. Evidence on the current growing importance of party politics in South African civil society (Friedman 2010) tends to confirm this hypothesis; we argue elsewhere (Benit-Gbaffou, forthcoming) that party structures are also more prominent as means for the poor to access the State, because local government participatory structures do not fulfil their promises, and the ANC-dominated party system does not allow for State accountability either in the absence of real party competition. This growth of party influence in civil society, directly or indirectly triggered by decentralization and participation reforms of local government, tends to reinforce the fourth characteristic, a civil society strongly dependent on parties and the State. However, as argued here, the link between civil society and political parties is ambiguous. It is not always disempowering for residents because it provides another modality or channel of access to the state for low-income residents.

\section{References}

Abers, R. (1998) 'From Clientelism to Cooperation: Local Government, Participatory Policy, and Civic Organizing in Porto Alegre, Brazil', Politics and Society 26(4): 511-538.

Akinyele, R. (2006) 'Urban experience in Lagos - White Caps Chiefs, Land Grabbers and Victims', presentation to the conference 'Inclusive African Cities', DBSA-HSCR-Wits, Johannesburg, 13-15 March.

Arnstein, S. (1969) 'A Ladder of Citizen's participation', Journal of the American Institute for Planners, 35: 216-224.

Auyero, J. (1996) 'Performing Evita: Brokerage and problem-solving among urban poor in Argentina', working paper, New York: Center for Studies of Social Change, $26 \mathrm{p}$.

Auyero, J. (1999) 'From the client's point of view': how poor people perceive and evaluate political clientelism', Theory and Society 28: 297-334.

Auyero, J., Lapegna, P., Page Poma, F. (2009) 'Patronage Politics and Contentious Collective Action: A Recursive Relationship', Latin American Politics and Society 51(3), pp. 1-31.

Bardhan, P. and Mookherjee, D. (2006) Decentralization, Corruption and Government Accountability: An Overview', in Rose-Ackerman, S. (eds), International Handbook of the Economics of Corruption, pp. 161-188 Edward Elgar Publishing.

Ballard, R., Habib, A., Valodia, I. (2006) Voices of Protest. Social Movements in post-apartheid South Africa. Durban: UKZN Press. 
Bayat A. (1997) 'Un-civil society: the politics of informal people', Third World Quarterly 18(1): 5372.

Bénit-Gbaffou, C. (2008) 'Are practices of local participation sidelining the institutional participatory channels? Reflections from Johannesburg', Tranformation: Critical Perspectives on Southern Africa 66-67: 1-33.

Benit-Gbaffou, C. and Morange, M., (2008) 'Sécurité et gouvernance flexible à Johannesburg et au Cap : légiférer pour gouverner?', Espaces et Sociétés 134(3): 19-35.

Benit-Gbaffou, C., (forthcoming) 'Party politics, civil society and local democracy - Reflections from Johannesburg', Geoforum, 2011.

Brinkerhoff, D., Goldsmith, A., (2002) 'Clientelism, Patrimonialism and Democratic Governance :An Overview and Framework for Assessment and Programming' Working paper prepared for the U.S. Agency for International Development, Office of Democracy and Governance.

Briquet, J.L. and Sawicki, F. (eds) (1998) Le clientélisme politique dans les sociétés contemporaines. Paris: PUF.

Corbridge, S., Williams, G., Srivastava, M. and Veron, R. (eds) (2005) Seeing the State: Governance and Governmentality in India. Cambridge: Cambridge University Press.

Cornwall, A. (2008) 'Unpacking 'participation': models, meanings and practices', Community Development Journal, 43(3): 269-283.

Cornwall, A. and Coelho V. (eds) (2007) Spaces for Change? The politics of citizenship and participation in new democratic arenas. London: Zed Books.

Cook, B. and Kothari, U. (eds) (2001) Participation: the new Tyranny? London: Zed Books.

Dahl, R. (1956) A preface to democratic theory. Chicago : University of Chicago Press.

Fuller, C.J. and Bénéï, V. (eds) (2001) The everyday State and Society in Modern India. London: Hurst and Co.

Friedman S., (2010) 'Beneath the Surface. Civil Society and democracy after Polokwane', in N. Misra-Dexter and J. February, Testing democracy: which way is South Africa going?, pp. 117-141 Cape Town: IDASA.

Gay, R. (1998) 'Rethinking clientelism: demands, discourses and practices in contemporary Brazil', European Review of Latin American and caribbean studies, 65: 7-24.

Gay, R. (1999) 'The Broker and the Thief: a parable. Reflections on popular politics in Brazil', LusoBrazilian Review 36(1): 49-70. 
Harriss, J. (2002) 'Political Participation, Representation and the Urban Poor. Findings from Research in Delhi', Economic and Political Weekly, 12March, 1041-1054.

Harriss, J., Stokke, K. and Törnquist, O. (eds) (2004) Politicising Democracy: the new local politics of democratisation. New York: Palmgrave McMillan.

John, P. (2009) 'Why Study Urban Politics?', in J.Davies, D. Imbroscio, Theories of Urban Politics, pp. 17-24 London: Sage.

Keefer, P. (2002) Clientelism, Credibility and Democracy. Working paper, DC: World Bank, Development Research Group.

Keefer, P. (2005) Democratisation and clientelism: why are young democracies badly governed? World Bank Policy Research Working Paper No. 3594, DC: World Bank, Development Research Group.

Khan, M. (2005) 'Markets, States and Democracy: Patron-Client Networks and the Case for Democracy in Developing Countries', Democratization 12(5): 704-724.

Kitschelt, S. and Wilkinson, S. (eds) (2007) Patrons, Clients and Policies: Patterns of Democratic Accountability and Political Competition. Cambridge: Cambridge University Press.

Lindell, I. (2008) 'The Multiple Sites of Urban Governance: Insights from an African City', Urban Studies 45(9): 1879-1901.

Low, M. (2007) 'Political parties and the city: some thoughts on the low profile of partisan organisations and mobilisation in urban political theory', Environment and Planning A 39(11): 26522667.

McAdam, D., McCarthy, J., Mayer, N. Zald (eds) (1996) Comparative perspectives on social movements: political opportunities, mobilizing structures, and cultural framings. Cambridge: Cambridge University Press.

Médard, J.F. (1973) 'Corruption in the Neo-Patrimonial States of Sub-Saharan Africa', in S.N. Eisenstadt. (ed) Traditional Patrimonialism and Modern Neo-Patrimonialism. London: Sage.

Miraftab, F. (2004) 'Invited and Invented Spaces of Participation: Neoliberal Citizenship and Feminists' Expanded Notion of Politics', Wagadu 1: 1-7.

Mohan, G. and Stokke, K. (2000) 'Participatory Development and Empowerment: the Danger of Localism', Third World Quarterly 21(2): 247-268.

Purcell, M. (2006) 'Urban democracy and the local trap', Urban Studies 43(11): 1921-1941.

Rakodi, C. (2002) 'Order and disorder in African cities: Governance, politics and Urban land development processes', in O. Enwezor, C. Basualdo, U. Bauer, S. Ghez, S. Maharaj, M. Nash, O. Zaya (eds) Under siege: Four African cities - Freetown, Johannesburg, Kinshasa, Lagos, pp. 45-80 Documenta11_ Platform 4, Ostiledern-Ruit, Germany: Hatje Cranz,. 
Schedler, A. (1999) 'Conceptualising accountability', in A. Schedler, L. Diamond and M. Platner. (eds) The Self-Restraining State: Power and Accountability in New Democracies, pp. 13-28.Boulder and London: Lynne Rienner.

Scott, J. (1998). Seeing like a state. How Certain Schemes to Improve the Human Condition Have Failed. New Haven, CT: Yale University Press.

Simone, A. (2004) For the City yet to come. Changing African Life in Four Cities. Durham: Duke University Press.

Sinwell, L. (2009) 'Participation as popular agency: the limitation and possibilities for transforming development in the Alexandra Renewal Project', unpublished PhD thesis (Development Studies), University of the Witwatersrand.

Staniland, L. (2008) “ "They know me, I won't get any job": public participation, patronage, and the sedation of civil society in a Capetonian township', Tranformation: Critical perspectives on Southern Africa 65-66: 34-60.

Swilling, M. (ed) (1997) Governing Africa's cities. Johannesburg: Witwatersrand University Press.

Tostensen, A., Tvedten, I. and Vaa, M. (eds) (2001) Associational life in African cities. Popular responses to the urban crisis. Stokholm: Elanders Gotab.

Véron, R., Williams, G., Cordbridge, S. and Srivanasta, M. (2006) 'Decentralised Corruption or Corrupt Decentralisation? Community monitoring of Poverty-Alleviation Schemes in Eastern India', World Development 34(11): 1922-1941.

Watson, V. (2002) 'The Usefulness of Planning Normative Theories in the Context of Sub-Saharan Africa', Planning Theory 1(1): 27-52.

Williams, G. (2004) 'Evaluating Participatory Development: tyranny, power and (re)politicisation', Third World Quarterly 25(3): 557-579.

World Bank (1996). The World Bank Participation Sourcebook. Washington, D.C.: World Bank.

World Bank (2000), Reforming public institutions and strengthening governance: a World Bank Strategy. DC: the World Bank.

\footnotetext{
${ }^{1}$ University of Witwatersrand, School of Architecture and Planning, claire.benitgbaffou@wits.ac.za.

${ }^{2}$ This research is part of 'The voice of the poor in urban governance: civil society, the state and party politics in South African cities' (2008-2011), funded by the French Institute of Research for Development (IRD).

${ }^{3}$ SANCO, officially allied to the ANC even if it has some local autonomy, is a national organisation, with regional structures as well as local structures based on ward boundaries.

${ }^{4}$ For public housing, the nature of the problem might be different.
} 
${ }^{5}$ The leader is said to have even taken all contributors by bus to a place called 'Florence Park', where the houses were to be built, to convince them that she had power to deliver.

${ }^{6}$ Except for 4 of the 17 houses which needed to be demolished.

${ }^{7}$ But with a high degree of pragmatism when it comes to global events whose national strategic importance might override such principles.

${ }^{8}$ Some argue referring to Brazilian cities (see Gay 1998), that it is the main existing form of political accountability to the poor.

${ }^{9}$ Although the exact nature of each form of governance is obviously not understood in the same way by each set of actors (Cornwall 2008).

${ }^{10}$ See Bénit-Gbaffou and Morange (2008) on security local arrangements in South African cities and 'flexible governance'.

11 One could question the democratic character in practice of Arnstein's last step of the participatory ladder: 'citizens' control' (Arnstein 1969).

${ }^{12}$ See Benit-Gbaffou 2008; Buire in this issue; Sinwell 2009; Staniland 2008. 